\title{
THE CONCEPT OF CULTURAL AND EDUCATIONAL SPACE IN PEDAGOGICAL DISCOURSE
}

\author{
OLESIA SMOLINSKA, KHRYSTYNA DZYUBYNSKA
}

\begin{abstract}
This article is devoted to the problem of definition of approaches of cultural and educational space on the basis of conceptual accents, depending on the purpose of the research. Such hermeneutic aspects are paid attention to as: the problem of correlation between the concepts of climate, environment and space, which are used in pedagogical discourse with similar meanings. The clarification of the content of the cultural and educational space is vital in the interdisciplinary context of philosophy, cultural studies and sociology, since all these scientific disciplines are involved in the formation of the contents, which circulate in the pedagogical discourse. The article eliminates the criteria for the definitions of cultural and educational space by different authors and generalized formulations, which arise from these criteria. In particular, the distinction is made by the following criteria: the physical organizational factor, the organizational and managerial category, the factor of pedagogical influence, the system of coordinates/ values, the communicative space, the object of philosophical and educational discourse, the factor of the formation of the subjectivity of an individual, circumstances of the reality metaphorization while its wording.
\end{abstract}

Keywords: cultural and educational space, pedagogical discourse, climate, environment, criteria of definition.

\section{INTRODUCTION}

The solution to the hermeneutical issues in pedagogy is usually connected with the need to analyze a large number of concepts and their interpretations. Because of this reason, researchers have to prove thoroughly the choice of the object of such a research that is based on its conformity with the purpose of the study, the breadth of the sphere of its usage.

A considerable number of facts, which are studied by the modern pedagogical science, specifically shifted the attention of researchers from the content of the object, as its hermeneutic essence, to the conditions of its existence, that is, on the phenomenological aspect. This phenomenon was called the "phenomenological shift" (M. Savchyn). As well as in the practical pedagogy, there is a characteristic desire of the relinquishment of subjects (the researcher from the object under study, the teacher from the object or subjects of study) to prevent the subjectivism.

The problem of the partiality of objects in pedagogical research, their fragmental nature lowers the research opportunities, isolating separate objects from the general field of pedagogical reality. Therefore, we believe that all the pedagogical research must be conducted, taking into account the 
spatial-temporal relation between diverse and heterogeneous objects. Consequently, in such a way, researchers will face the necessity to generalize a very large number of specific features. These studies can be based on the thesis that there is a significant amount of important features, that are inherent to both the system of education in general, and to its components (separate institutions) in particular. In Ukraine, the process of decentralization and deregulation in higher education has just started. It is connected with the adoption of the new Law of Ukraine "About Higher Education" (2014), therefore, there are enough common significant features adherent to individual educational institutions.

The clarification of the content of the unified space of university's culture and education - is rather extensive, and not a new task, but the changes in the content of higher education in both national and global dimensions also generate significant changes in the understanding, and methods of explanation of the concept content "cultural and educational space". Due to this urgent task, there are hermeneutic accents in its definitions, which will enable researchers to use general methodological approaches, without being absorbed in the study of a large number of definitions each time.

\section{RESULTS AND DISCUSSION}

The analysis of literary scientific sources enabled us to formulate several aspects of this problem:

1. The correlation of concepts of climate, environment and space, which are used in similar meanings by the authors.

2. The nature of the cultural and educational space of the university: philosophical, cultural or social?

3. The classification criteria of the definitions of cultural and educational space.

\subsection{Climate, EnVironment AND SPace: What IS THE DifFerence?}

Thus, the first issue, regarding the correlation between the concepts of the climate, an environment and space, from the aspect of the unity of university culture and education, was usually solved depending on the historical stage and the general tasks of education. The history of the studies of pedagogical categories of the methodological level, which comprise the category of cultural and educational space, is quite old. First of all, on the territory of Ukraine, there is a study of the late Soviet period about the social and psychological climate, methodologically based on the theory of the collective (group). Later, the study of functional environments gained popularity and corresponded to

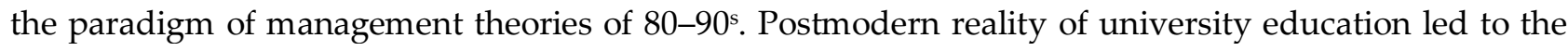
integration of cultural, social and organizational theories, linking them in the broad context of the specific space.

In spite of the proximity of these three alternatives: the internal climate (microclimate), environment or space, first of all, making the choice, one should be guided by the purpose of the study. In our opinion, their usage is closely connected with the philosophical categories of individual, special and general, that are disclosed through the content of the object under study, where the unitary - is the way of being of general, and special - is its concrete expression. Thereby, the unitary (in this article the climate) - is a way of the space existence, and the environment - is its specification. Regarding the educational research -climate exists at the level of social groups (pupils, students and teachers), environment - at the level of their interaction, and space is manifested as their teleological stipulation.

Therefore, the evolution of the concepts about space includes its development from the categories of microclimate, environment, the last one is the most widespread with a large number of definitions (educational, informational, cultural and social). The closest to the subject of the article are the contents of the concepts of "educational space", "educational environment", which have been used in the domestic pedagogical science since the $90^{\mathrm{s}}$ of the XX century, together with the category of culture in education. Originally, this category came to the pedagogy of the post-Soviet period from abroad, as an idea of "hidden curriculum" [13], "a curriculum, which is not studied" [35]. Once A. Asmolov characterized the essence of this phenomenon through the notion of superconscious - "the adopted samples of typical behavior and cognition of the certain community by the subject, as a member of one 
or another group, the impact of which is not really realized or controlled by the subject himself" [1], A. Leontiev and his students - as "the image of the world", a complete multilevel system of man's notions about the world, other people, himself and his activities [21], B. Elkonin - as "subjective attitude to the cultural form", which implies initiative and independence in the testing of cultural forms, where the essence of the organization of such type of testing, is collective and individual actions [9]. The ideas of informational pedagogy [29] and its semantic line "education-culture" of cultural and historical pedagogy [38], with its rehabilitating space, is close to the idea of cultural and educational space, since they assume the unity of education and culture, so that pedagogical experience transmits not only the concept of culture, but also the means, methods and conditions of its transmission. The idea of freedom in pedagogical activity, in particular, in the context of modeling cultural and educational space of an educational institution, deserves attention (O. Budnyk, $\mathrm{H}$. Vasianovych). "Teachers are able to realise their creativity and students' potential in the conditions of individual and social freedom" [36, p. 89]. The key ideas of educational studies are similar to these.

Concerning higher education, "non-zero memory" can serve as a specific notion of the content of space [31] and "deposited knowledge" ("intellectual surplus") [23], as the existence of scientific schools, is the key to a fundamental long-term oriented education. To our mind, it should be noted that the concept of the last author is quite controversial.

The generic correlation between the concepts of "educational space" and "cultural and educational space" is also complex, since the statements about the generic nature of education to culture or vice versa cannot be argued unambiguously. Modern authors [20], whose opinion we share, believe that formations of this type predetermine the emergence of specific scientific added value. Even there is a discussion in pedagogy, defining a "hidden curriculum" as an environment or space: on the one hand, there is a belief that space is the product of purposeful changes in the environment, its separate aspect, (V. Kyrychenko, I. Shendryk, N. Kasiarum), for example, I. Shendryk [28], working on the problem of designing of the educational space of the subject, proceeds from the fact that space is a mastered environment by a human (natural, cultural, social, informative) adapted for solving the corresponding tasks; the environment is given, and space is an acquirement. On the other hand - on the contrary, the environment (educational, informational) is an integral part of the space (cultural and educational, social and cultural, urban, ethno-cultural) [25]. Besides, a number of researchers, especially those who do not set the issue of space as a primary goal or support linguistic conceptualism, use them as synonymous (L. Novykova and M. SokolovskyN, H. Selyvanova). In this article, we accept the thesis that the environment is a special generating part of space, the combination of different types of environments into a single space, determining the synergistic effect, according to I. Kant, "we can imagine only one single space, and if we talk about many spaces, then we understand them only as parts of the same unified space" [17, p. 51], the content of the effect of these parts combination - is in their development, together with the scale of space (I. Shalaiev, S. Kryvykh). At the same time, we do not isolate the thesis about their possible synonymy.

Summarizing, we can note that there is a significant affinity between the notions of the cultural and educational environment and space, since both denote the environment of the subject (university), while the environment means immersion into a certain informational flow (A. Moles) to change and improve the human self, therefore - the involvement of the subject-person is necessary. Space implies not temporary, though long-term, immersion, but a permanent presence, where human participation is not obligatory, realizing its functions in a fatefully difficult moments, that is why nowadays the discussion of the problems of the space of education and culture in the Ukrainian and Russian research has been intensified.

Thus, the correlation of "environment-space" in university education also involves the correlation of "locality-globality", "physical reality-virtuality", without various complementary educational environments, that function in the dimensions of "socialization-individualization", "integrationdifferentiation" and "age-not age" [6] and, first of all, reacting to the formation of new niches, filling them. The following characteristic features of the space, given by G. Chelpanov [5, p. 227-231] coordinate with the previous statement, such as: a notion of the structure of space, where each element 
exists at the same time simultaneously and separately with regard to others; continuity as integrity, introduced by the way of its comprehension; homogeneity as identification of its constituent parts; infinity as an understanding of its potential. In addition, while discussing the inner essence of the university, which is its cultural and educational space, we should understand that it liable to qualitative changes, development as an immanent process, which is, a "continuing movement inside" and consists in establishing of such dependence and relationships, "which would allow to lead the following states to the previous ones, and then deduce them from the previous on the basis of these connections" [27, p. 171-172], which corresponds to Kant's duality in the comprehension of the humanitarian space. Thus, the usage of the category of space is more appropriate in relation to this object. Here, the following issue arises - the nature of space.

\subsection{Is the Nature of the Cultural and Educational Space of the University: Philosophical, CUltural or Social?}

A short review of the research confirms the need to select a position. In particular, concerning the philosophical space, in the future we will be guided by the culture-logical and ontological tradition, according to which the understanding of space and time is related to the practical activity of man (creation of culture), while the time - is the beginning, end, or duration of this activity, and space - is the correlation between own and other person's activities. Universals of the similar type can be assumed as - noosphere (T. de Chardin, V. Vernadsky); the intellectual sphere (A. Humboldt); the psycho sphere (O. Reiser); pneumatic sphere (P. Florensky); the spirit of time (G. Hegel); the spirit of the people (J. Herder); general mind (H. Gadamer); worldview (M. Pyrogov); mass consciousness (E. Durkheim); mass psyche (S. Freud); collective unconscious (C. Jung); the paradigm (T. Kuhn); episteme (M. Foucault); semiosphere (Yu. Lotman); value and sense universe (S. Krymsky); third world (K. Popper); system of intelligent matter [2].

Culture-logical conceptions of studying of the organization of space and time in their non-physical content are often realized in the context of metaphorization of activity, resulting - in the "performing" of certain cultural scenarios, the closest organizational model of which is their staging (performance). The organization of the cultural and educational space of the university, its interpretation can be also represented with the help of dramaturgical culture-logical models - metaphors [10, p. 2005] and theatrical (game) analogies [37]. In such a context, the university's cultural space is a certain area, where the playing activity arises and is regulated (according to the professional and cultural scenarios), as well as the creative activity of individuals that contributes to its preservation, and, at the same time, creates new cultural values [22]. A. Karmin [18, p. 203], defining the cultural space as a set of "all models and ideals of human activity and all cultural relations", also implemented an activity approach to its comprehension. The same statement was affirmed by P. Florensky, who identified culture as an environment, which brings up a personality, and argued that culture, in fact, "can be interpreted as the activity of space organization. In one case, this is the space of our life-affairs and the corresponding activity is called a technique. In other cases, this space is thinkable, thought-provoking model of reality, and the reality of its organization is called science and philosophy ... The third category of cases lies inbetween the first two ... The organization of such spaces is called an art" [12, p. 112].

The next concept of the cultural space - which lies beyond its physical contents - therefore can be called virtual (it has no physical incarnation); it institutionally brings it closer to education. In particular, A. Bystrova notes: "Cultural space - is also a space for the realization of human virtuality (deeds, abilities, skills, desires), the implementation of social programs, aims, interests, the spread of ideas and views, language and traditions, beliefs and norms, etc." [4, p. 39].

Expanding the notion of culture to the level of ontological category, "one should understand culture as a special form of existence, the substance of which is "culture"- that is an organic combination of spirit and matter"; at the same time, M. Kagan [16, p. 38] attaches the characteristics of space and time to culture, grounding the historical laws of its existence (self-preservation and uneven development of its various subsystems and elements). J. Dewey also sticks to the similar views, 
recognizing the ability of culture to self-preservation and its organizational influence on the configuration of the order and structure of aspirations and activities of any group [5, p. 38-45] and, at the same time, it performs the role of the restrictor-emancipator. This virtual approach opens up the possibility of historical research of the genesis of cultural and educational space both at the institutional level of education, and also at the micro level of the university.

In the context of sociological approaches to understanding the content and genesis of the category of social and cultural space, a thing that really matters is its progress, starting from G. Simmel and his sociology of space, where the vitally important characteristic of the latter is its passivity, objectivity, A. Comte [17, p.11-21] with his "social dynamics", which involves a number of evolutionary forms of the organization of thinking, the initial among which is theological, then go- metaphysical and positive, which correspond to the military, feudal and industrial phases. G. Spencer [33, p. 221], continuing the thesis of A. Comte, defined the three-component structure of social space as an organism, whose functioning is provided by specific bodies - social institutions, separating the internal and external subsystems, as well as the intermediate, symbolic (culture, language), which links them and, in such a way, organizes the space and functionally builds the boundary from the sphere of efficiency of cultural and educational space. According to it, the genesis of non-biological space was considered by the scientist from the point of view of social Darwinism in biological terminology. Furthermore, choosing between two types of organizations, E. Durkheim [7, p. 286] preferred organic (appears in an industrial society on the basis of the division of labor as a new fact of common consciousness) over mechanical (which is inherent to the pre-industrial era), while admitting that the states of consciousness depend on the way of communities organization, the quality of interactions within them, "because they are the products of group life, so only the nature of the group can explain them" [7, p. 292]. P. Sorokin gave the phenomenological explanation [32, p. 298] to the meaning of the social space, as "a certain universe consisting of the population of the Earth" and the ability to determine the position of a man or phenomenon in it through determination of their relations to "starting points" - other people or groups, this explanation is close to the explanation of socio-spatial relations, which was made by E. Durkheim. The same idea was expressed by $\mathrm{Ch}$. Cooley in the context of communicational space, describing the mechanism of its development: "Symbols, traditions, institutions are projected outside the mind and then make a reverse effect, controlling the mind, stimulating, developing and consolidating some thoughts at the expense of others, which are closed to the impulses that can awaken them" [7]. P. Bourdieu explained the meaning of the concept of social space as "an abstract, formed with an ensemble of subspaces or fields (economic, intellectual) ..., one that strives for being realized in it (in the physical space - author's) more or less completely and accurately" [3, p. 53]. Proceeding with the topic of heterogeneity of the content of the social space, this author [11] distinguishes three aspects of social space studying, namely: as the space of interaction of social operators (P. Sorokin, A. Giddens), as a metaphorical space of social factors (G. Simmel), as the place of location of objects and subjects, which is physically available (E. Durkheim, M. Weber) or immense: streams (M. Castells), fields (P. Bourdieu). I. Shendryk [28] classified the definition of social space in the following way: as a result of the interaction of the natural environment and human activity; as contemplation and representation, observation and social analysis, that is expressed in theories of interpretation of meanings; as the interaction of space and time, the form of social being; as multileveled and heterogeneous, representing the historical context of the matter movement and the transformation of social energy into the concrete forms of life of a society and its structures; as the personally notional formation of the space - the spiritual component of human life; as a result the subject-subjective interactions ("horizon" by E. Husserl, "prospective" by K. Jaspers, "landscape" by M. Heidegger, "life world" by E. Husserl and A. Schütz). The last criterion has become widespread among Ukrainian and Russian researchers nowadays.

Consequently, the sociological direction of non-biological space concept studying (including cultural and educational) gives the opportunity to define it as an abstract and symbolic aspect of existing relationships between people within different groups, including professional, the study of which gives the possibility of cross-examination of individuals and the groups, which they belong to. In 
addition, this type of space is meaningfully structured, depending on micro groups or types of interactions, and it develops, evolves both due to the effects of other spatial-group entities, and due to its own influence on them. The expediency of usage of the methodological achievements of sociology in the field of social space studying in pedagogy is confirmed by E. Durkheim, who stated in the lecture "Pedagogy and Sociology": "I personally think that the basis of any theoretical construction in pedagogy is the following statement: education - is a phenomenon, mainly, social both by its functions, and by origin, therefore, pedagogy depends on sociology..." [8]. At the same time, grounding the thesis of the dependence of education on the content of social relations, the scientist found it in culture, in its general human contexts, thanks to which it becomes possible to overcome the social differentiation, to harmonize the pedagogical ideal, which depends on the social structure.

Social space and time develop in unity, but unequally, forming a social chronotope (time and space), which was described by A. Ukhtomsky in the context of research on physiology, and M.Bakhtin - in literary studies, thanks to the latter writer, this concept was spread to humanitarian research. Modern authors consider metaphors as means of organization of pedagogical chronotope - they are mediators of interactions and communications with "two referents: values, meanings and a particular pedagogical situation" [26, p. 136].

\subsection{Cultural and Educational Space: Classification AND Definitions}

The study of cultural and educational space can be classified in different ways, namely: depending on the level of education and the type of educational institution (N. Kasiarum). In connection with this, there are a number of studies dedicated to the educational space of a preschool educational institution (K. Krutiy, O. Litichenko, N. Kolosova), general secondary school (A. Tsymbalaru, A. Tsuker, V. Yasvin, G. Kovaliov and Yu. Abramova, K. Prykhodchenko, A. Katashov), vocational education (E. Zeyer and I. Mieshkova, A. Rosstalnoy, S. Aloshina), higher educational establishments, including universities (A. Bondarevskaya, T. Isaieva and O. Rubanyk, T. Meng, S. Belikova, O. Pisotska).

In addition, a qualitative typology of spaces is performed: informational and educational (L. Gorbunov), artistic and educational (L. Troielnikova), literary and educational (L. Kalachova and A. Popova), multicultural educational (Ya. Poliakova, O. Demydenko), vocational educational (E. Zeier and I. Mieshkova, V. Gordienko), a pedagogically comfortable environment as a phenomenon that contributes to the transformation of the educational environment into a cultural space (I. Larisova), dialogical space (V. Hordienko and L. Kopets), integral humanitarian educational space (O. Danyliuk), semiotic (V. Dreshpak), viable space in the educational process (N.Solovyova), spiritual space of educational institution (M. Leshchenko).

There are attempts of functional classification, for example, T. Tkach [34, p. 759-760] distinguishes cultural and educational spaces, depending on the index of combination that, firstly, belong to different spheres of culture: philosophy, pedagogy; and secondly, educational systems on a global scale; the third approach links the space with the system of educational technologies, extra-curricular work, management, interaction with other social institutions, interrelations between education and society as a whole.

We consider that it is necessary to classify the definition of the concept of cultural and educational space (and used by the authors in synonymous meaning with other spatial constructs) according to the following criteria:

1. The definition of the cultural and educational space as the physical factor of the spatial organization (educational environment as an organized school space (M. Isaieva, O. Leonova), and numerous studies on ethno-pedagogical themes, which are similar to this understanding. According to this criterion, the cultural and educational space of the university - is an organized order of events, as a result of purposeful teachers' activity, and their external circumstances, which are considered correct within a specific university, the system of the corresponding institutions, national or public education.

2. Cultural and educational space as an organizational and managerial category (single educational space (N. Rybka, I. Malyukova and co-authors, S. Zdioruk and co-authors); organizational culture of vocational and educational environment (V. Hordienko), single educational and scientific space 
(Kh. Oleksyk), the factor of the modernization of pedagogical education (I. Nabok). This approach makes it possible to define the university's cultural and educational space as - an organized ground, aiming at optimization of management, whose main function is legitimization of certain decisions that correspond to its parameters for their further successful implementation.

3. Cultural and educational space as a factor of pedagogical influence (the factor of formation of project and technological culture of the future teacher of technologies and drawing (V. Moshtuk); the factor of the influence on the development of students' subjectivity (T. Ravchyna); the factor of a modern specialist formation (N. Chybisova); the pedagogical potential of higher educational institution corporate culture (M. Bielyaieva); the determination of the professional and personal formation of the future engineer (N. Niemtsova); the basis for the creation of the technology of development of pedagogically talented future teachers (H.Golubova); organized in a special way social and pedagogical environment that stimulates both the development and self-development of its every member, a system of proper conditions for personal and creative development (N. Shchigolieva); a set of educational programs that are implemented by educational institutions, informational products created by the media and available on the internet that can affect the individual direction of personality's development (The institute of innovational activity in education of the Russian Academy of Education); the factor of pedagogy of environment, the "brine" (the static external environment concerning an individual, where he is an element, and has to be arranged in the context of the environment), or "jazz" (a non-static environment, the arrangement of heterogeneous, beyond which the elements lose their quality, that exists only as a moment or an effect of subject interaction, where an individual is the result of the process of his own activity) [15]; educational space, which creates potential of abilities (V.Shpak). In general, this criterion stipulates the following definition of cultural and educational space of the university: it is the basis and the target of the individual and collective types efforts direction to reach the goals of high-quality vocational and pedagogical training.

4. Cultural and educational space as a coordinate system / landscape for social and ethnic values (educational space as a worldview and valuable basis of the social and cultural development of society (O. Marchenko); the paradigm of values orientations and transformations of society (I. Mukhina), reaction to social tendencies (O. Andropova), the transmitter of universal human values and the values of national culture to the younger generation (O. Malytska); the result of the conceptualization of the educational system development (H. Zakharova)). According to the analysis of the above-mentioned definitions, the cultural and educational space of university - is an institutional formation, which generates its own rules and grounds its own values, at the same time, it is also selectively open to other similar social institutional formations, with which the cultural exchange of values takes place.

5. Cultural and educational space as a space of social and psychological communication (adaptation factor (E. Gingel, V.Streltsova); circumstances of socialization (V. Labunskaya). While defining cultural and educational space of the university in social and psychological context, patterns' features and ways of identification in it, take the first place. Therefore, the cultural and educational space - is a totality of cultural samples, which are formed as a result of experiencing certain events on the university scale, its life experience, which serves as a standard to follow for beginners, and it forms patterns for their further vocational and educational activities, by passing it from generation (teachers and students) to generation (teachers and students), including the combinations of "teacher-teacher", "student-student".

6. Cultural and educational space as an object of philosophical and educational discourse, in particular, "the form of modern education existence" (A. Bondarevskaya); the object of structuring (N. Radionova); the environment of personality humanization (I. Kadiyevskaya); the category of the philosophy of education, which reflects the peculiarities of the structural transformation of intellectual life (V. Kremin); a pedagogical phenomenon of meeting and interaction between a person and the surrounding elements - culture carriers, which results in their comprehension and cognition (A. Tsymbalaru). As an object of philosophical and pedagogical discourse, the cultural and educational space of the university is an ontological category, a phenomenon, the study of which is possible in collective and individual contexts as a specific reflection on the events, and the comprehension takes 
place in the field of hermeneutics by revealing the textual and contextual contents of internal and external events, with respect to the boundaries of this space.

7. Cultural and educational space as a factor of the formation of a person's subjectivity (G. Gerasimov, I. Shendryk, T. Tkach), "a soft framework of potential that surrounds and penetrates into the tissue of educational interactions, the epicenter of which -is the main subject of education - the person, who studies" [19, p.138]. The university's cultural and educational space in the dimension of subjectivity - is a special reflection of the synthesis of heterogeneous cultural and educational influences on the features of an indigenous personality (person or university), who or which was active in the formation of this reflection.

8. Cultural and educational space as a circumstance of metaphorization and wording of reality (M. Elvesson, V. Onyshchyk, V.Sydorova), an educational system of personal-development type, where the systematic translation of educational information into the languages of various sciences and arts is possible. (O. Danyliuk). From these points of view, the cultural and educational space of the university - is a prism of changing the information and, as a result, it acquires an individually valuable content, being transformed from the external into internal, turning into a symbolic university, professional or personal reality.

The definition itself is worded in the following way: "the cultural and educational space of the university is a special type of the local chronotope, which appeared as a result of individual and collective subject activities for the mastering of applied value-oriented, symbolic and sign professional reality, that, in its turn, stipulates both the parameters of this reality, and the activity of subjects in relation to its development and organization" [30, p. 47].

\section{CONCLUSIONS}

Having analyzed the approaches of pedagogy, philosophy, cultural studies and sociology, concerning the definition of cultural and educational space, we observe that they coincide at the point of defining it as the cause and result of symbolization of subjects interactions, that take place in a certain physical and intellectual landscape, creating a new cultural and temporal reality, which can be of different character (professional and pedagogical, social, cultural, scientific, etc.). The distinguishing of the key content of the definition (its criterion) reveals its hermeneutic emphasis, therefore, depending on the purpose, researchers use different definitions of the same concept. This leads to polycontextuality, which, on the one hand, "blurs" the hermeneutic framework, and on the other hand prevents their conservation, provides an opportunity for the creation of new scientific messages.

The perspective of the further development in this direction is considered in the formation of the methodological basis of the educational research, and besides, the prerequisite for the formation of specific strategies for the development of cultural and educational spaces of universities.

\section{REFERENCES}

[1] Asmolov A. On the other side of consciousness: the methodological problems of non-classical psychology. Smysl, Moscow, 2002. (in Russian)

[2] Bazaluk O. Intelligent matter. Naukova dumka, Kyiv, 2000. (in Russian)

[3] Bourdieu P. Sociology of social space. Aleteiia, Saint Petersburg, 2007. (in Russian)

[4] Bystrova A. Cultural space as a subject of philosophical reflection. Filosofskiye nauki, 12 (2004), 24-42. (in Russian)

[5] Chelpanov G. Psychology. Philosophy. Education. NPO "Modek", Voronezh, 1999. (in Russian)

[6] Comte A. The spirit of positive philosophy: the word about positive thinking. Knizhnyy dom "Librokom", Moscow, 2011. (in Russian) 
[7] Dobrenkov V., Belenkova L. Texts on the history of sociology in the XIX-XX centuries. Reader. Nauka, Moscow, 1994. (in Russian)

[8] Durkheim E. Pedagogy and Sociology. In: Durkheim E. Sociology. Its subject, method, purpose. Kanon, Moscow, 1995. Available at: http://janex.narod.ru/Shade/socio.htm. (in Russian)

[9] Elkonin B. Pedagogy of development: experimental action as a basis of education. Available at: http://www.experiment.lv/rus/biblio/vestnik_11/v11_elkonin.htm. (in Russian)

[10] Elvesson M. Organizational culture. Izd-vo Gumanitarnyy Tsentr, Kh., 2005. (in Russian)

[11] Filippov A. Elementary sociology of space. Sotsiologicheskiy zhurnal, 1 (1995), 45-69. (in Russian)

[12] Florenskiy P. Collection of works. Articles and studies on the history and philosophy of art and archaeology. Mysl, Moscow, 2000. (in Russian)

[13] Frumin I. Introduction to the theory and practice of democratic education. Znaniye, Krasnoyarsk, 1998. (in Russian)

[14] Gerasimov G. Socio-pedagogical dimension of the cultural and educational space. Materialy IV Vserossiyskogo sotsiologicheskogo kongressa "Sotsiologiya v sisteme nauchnogo upravleniya obshchestvom", 18, 1045-1046. Available at: http://all-russia-sc.ru/netcat_files/File/Part18.pdf. (in Russian)

[15] Gusakovskiy M. Instead of the conclusion. University as the center of cultural development. Change the forms of communication in the learning process. BSU, Minsk, 2004. Available at: http://elib.bsu.by/bitstream/123456789/8083/1/koll_monogr_2004.pdf. (in Russian)

[16] Kagan M. Ontology of culture. Paradigma: filosofsko-kulturologicheskiy almanakh, 11 (2008), $28-51$. (in Russian)

[17] Kant I. The criticism of clear mind. Taim-aut, Saint Petersburg, 1993. (in Russian)

[18] Karmin A. Fundamentals of Cultural Studies: the morphology of culture. Lan, Saint Petersburg, 1997. (in Russian)

[19] Kisil M. The space of education from the point of view of its main subject. Visnyk Cherkas'koho universytetu. Seriya "Pedahohichni nauky", 88 (2006), 138-141. (in Ukrainian)

[20] Korsakova T., Korsakov M. Way of life of the educational organization: an intellectual model. American Journal of Educational Research, 1 (5) (2013), 156-161.

[21] Leontyev A. The image of the world. In: Leontyev A.N. Izbrannyye psikhologicheskiye proizvedeniya $\mathrm{v}$ 2 t. Pedagogika, Moscow, 1983. (in Russian)

[22] Orlova E. Cultural space: definition, features, structure. Analitika kulturologii, 3 (18) 2010. Available at: http://www.analiculturolog.ru/journal/archive/item/589-cultural-space-structure-determination-ofspecificity.html. (in Russian)

[23] Panarin A. Christian fundamentalism against the market terrorism. Nash sovremennik, 1 (2003), 166-178. Available at: http://club.geurasia.org/index.php?act=attach\&type=post\&id=2094. (in Russian)

[24] Philosophy reader. In: Volynka H.I. Zarubizhna filosofiya XX stolittya, 6. Dovira, Kyiv, 1993. (in Ukrainian)

[25] Radul V. Social maturity of a young teacher. Vyshcha shkola, Kyiv, 1997. (in Ukrainian)

[26] Senko Y. Humanitarian foundations of pedagogical education. Akademiya, Moscow, 2000. (in Russian)

[27] Shchedrovitskiy G.P., Rozin V.M., Alekseyev N.G., Nepomnyashchaya N.I. Pedagogy and logic. Kastal, Moscow, 1993. (in Russian)

[28] Shendryk I. The educational space of the subject and its design. APKiPRO, Moscow, 2003. (in Russian)

[29] Smirnov V. Informational pedagogy. In: Varlamova T.P., Eremina I.S., Efimova L.P. (Eds) Teoriya, metodika i organizatsiya pedagogicheskoy raboty, 2. SIBPRINT, Novosibirsk, 2010. (in Russian)

[30] Smolinska O. Theoretical and methodological foundations of the organization of cultural and educational space of Ukrainian pedagogical universities. Universytetska knyha, Sumy, 2014. (in Ukrainian)

[31] Solodova E. Educational problems and new models of educational processes. Available at: http://spkurdyumov.ru/education/problemy-obrazovaniya-i-novye-modeli-obrazovatelnyx-processov/. (in Russian)

[32] Sorokin P. Human. Civilization. Society. Politizdat, Moscow, 1992. (in Russian)

[33] Spenser G. Synthetic philosophy. "Nika-Tsentr", Kyiv, 1997. (in Russian) 
[34] Tkach T. Methodological foundations of the research of personality's educational space. Collection of research papers Kamianets-Podilskyi National Ivan Ohienko University. G.S. Kostiuk Institute of Psychology at the National Academy of Pedagogical Science of Ukraine, 18 (2012), 757-766. (in Ukrainian)

[35] Washburne K. New schools in Western Europe. Posrednyk, Moscow, 1928. (in Russian)

[36] Vasianovych H., Budnyk O. The Category of freedom in the written heritage of John Amos Comenius and Hryhoriy Skovoroda. Advanced Education, 7 (2017), 85-89. doi: 10.20535/2410-8286.93517

[37] Voskanyan M. Play in an individual-oriented society. Obshchestvennye nauki i sovremennost, 2 (2009), 170-176. (in Russian)

[38] Yamburg E. Outlines of cultural and historical pedagogy. Pedagogika, 1 (2001), 3-10. (in Russian)

Address: Olesia Smolinska, Khrystyna Dzyubynska, Stepan Gzhytskyi National University of Veterinary Medicine and Biotechnologies Lviv, 50, Pekarska Str., Lviv, 79010, Ukraine.

E-mail: smolinskao@gmail.com, dzyubynskakhr@gmail.com.

Received: 15.11.2017; revised: 14.03.2018.

Смодінська Олеся, Дзюбинська Христина. Поняття кудьтурно-освітнього простору університету в педагогічному дискурсі. Журнал Прикарпатського університету імені Василя Стефаника, 5 (1) (2018), 55-64.

Ця стаття присвячена визначенню підходів до дефініції кудьтурно-освітнього простору на основі змістових акцентів залежно від мети дослідження. Крім того, автори статті звертають увагу на такі аспекти герменевтики, як проблема співвідношення понять кдімату, середовища та простору, які вживаються в педагогічному дискурсі у близьких значеннях. 3'ясування змісту культурно-освітнього простору актуальне в міждисциплінарному контексті філософії, культурології та соціології, оскільки так чи інакше всі ці наукові дисципліни задіяні у формуванні змісту, що циркулюють у педагогічному дискурсі. У статті визначені критерії для визначення кудьтурно-освітнього простору різними авторами та узагальнені формулювання, що випливають із цих критеріїв. Зокрема, виокремлені означення за критеріями: фізичного організаційного фактору, організаційно-управлінської категорії, фактору педагогічного впливу, системи координат/ландшафту цінностей, комунікативного простору, об'єкта філософсько-освітнього дискурсу, фактору становлення суб'єктності особистості, обставини метафоризації дійсності при її обумовленні.

Ключові слова: культурно-освітній простір, педагогічний дискурс, клімат, середовище, критерії визначення. 